Dig Surg 1995;12:267

\title{
Contents, Vol. 12, No. 5, 1995
}

\section{Editorial}

Krähenbühl, L.; Büchler, M.W.

Laparoscopic Colon Surgery: Do We Need It?

269

International Results:

Laparoscopic Colorectal Surgery in Various Countries

Petropoulos P.; Kiesler, P.; Chanson, C; Nassiopoulos, K.; Steffen, R.

Laparoscopic Colorectal Surgery

271

Go, P.M.N.Y.H.

Laparoscopic Large Bowel Procedures

277

Fingerhut, A.; Millat, B.; Lointier, P.; Hay, J.-M.

Is Laparoscopic Colonic Resection for Carcinoma Feasible and Safe? A French Collective Experience

280

Franklin, M.E., Jr.

Laparoscopic Management of Colorectal Disease. The United States Experience

284

Köckerling, F.; Schneider, C; Reymond, M.A.; Wittekind, C.

Laparoscopic Colorectal Surgery:

Indications and Concept of a Multicenter Study

288

\section{Controversies}

Greene, F.L.

Laparoscopic versus Conventional Colon Surgery: What Are the Advantages?

293

Buchmann, P.; Christen, D.

Pro Laparoscopic Surgery for Colorectal Cancer

296

Seiler, C.A. $\quad$ Laparoscopic Resection for Colorectal Cancer: 302

A Safe Way to Cure Cancer?

Author Index, Vol. 12, No. 5, 1995 
